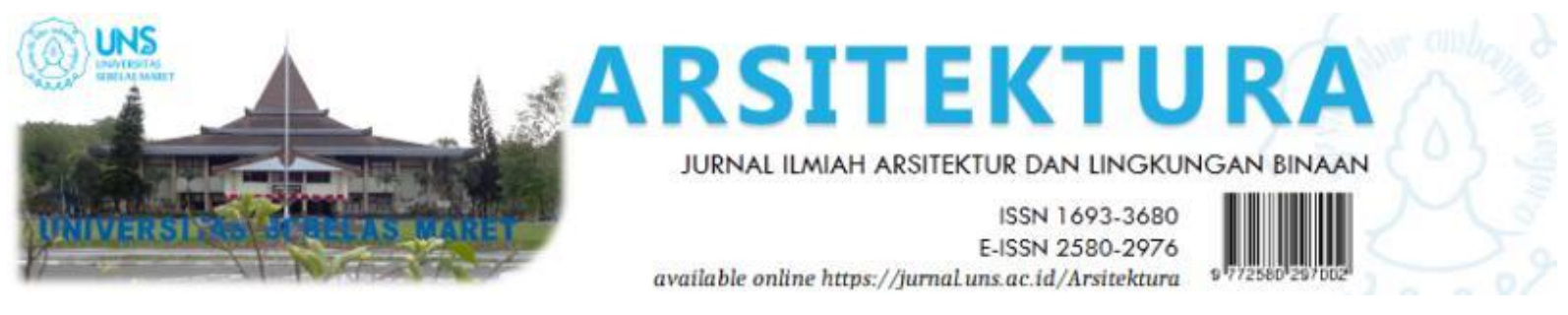

Volume 19 Issue 1 April 2021, pages:147-156

\title{
Identifikasi Potensi Wisata Situs Gua Song Gilap di Pracimantoro, Wonogiri, Jawa Tengah
}

\author{
Identification of Tourism Potency \\ in Song Gilap Cave at Pracimantoro, Wonogiri, Central Java
}

\author{
Raden Al Huda Belva Adinata Wicaksono ${ }^{1 *}$, Wiwik Setyaningsih ${ }^{2}$, Purwanto Setyo Nugroho ${ }^{3}$, \\ Ana Hardiana ${ }^{4}$, Ofita Purwani ${ }^{5}$ \\ Department of Architecture, Fa culty of Engineering, Universitas Sebelas Maret ${ }^{1^{*}}$ \\ belvaadinata42@student.uns.ac.id \\ Department of Architecture, Fa culty of Engineering, Universitas Sebelas Maret ${ }^{2345}$
}

DOI: https://doi.org/10.20961/arst.v19i1.47060

Received: December 28,2020 Revised: January 29,2021 Accepted: January 29,2021 Available online: April 30,2021

\begin{abstract}
Wonogiri regency has a huge potency, especially in its natural wealth. Limestone sites are very e a sy to find in wonogiri regency, but there are still manylimestone sites that are notoptimallymanaged so it is feared to be damaged and lost. The local govermment provides considerable support in developing the potency of the region in the field of tourism. Song Gilap Cave is one of the cavesites that has tourism potency in WonogiriRegency, especially in Pracimantoro District. The purpose of this research is to map the tourism potencyin Song Gilap Cave so that it can be developed optimally. The method of maping tourism potency in this research was carried out with SWOT analysis that discussed the strengths, weaknesses, opportunities, and threats at the site of Song Gilap Cave. The mapping resulted in several strategies for the development of the Song Gilap Cave site area which is expected to maximize the natural potential so that it can be a forumfor the surrounding community to develop themselves in the education, conservation, economic, social, and cultural fields.
\end{abstract}

Keywords: tourism, cave, potency, identification, strategy

\section{PENDAHULUAN}

Pariwisata merupakan sektor yang memiliki potensi besar untuk berkembang di Indonesia dan menjadi perhatian pemerintah. World Travel and Tourism Council (WTTC), pada tahun 2018, menempatkan Indonesia pada peringkat ke-9 sebagai negara dengan pertumbuhan wisatawan mancanegara tercepat di dunia (World Travel and Tourism Council, 2018 dikutip dari Samparaya, 2018). Potensi besar pariwisata Indonesia ditunjang oleh potensi besar pariwisata yang dimiliki oleh tiap daerah. Menurut Undang Undang nomor 10 Tahun 2009 tentang Kepariwisataan, yang dimaksud dengan pariwisata adalah berbagai macam kegiatan wisata dan didukung berbagai fasilitas serta layanan yang disediakan oleh masyarakat, pengusaha, Pemerintah, dan Pemerintah Daerah.

Kabupaten Wonogiri memiliki potensi besar pariwisata di bidang karst dan speleology. Wonogiri merupakan daerah dengan sumber 
daya alam kapur yang melimpah serta banyak memiliki gua karst. Potensi wisata tersebut dapat diolah secara optimal untuk menjadi solusi dari berbagai permasalahan wilayah dan dapat memajukan kualitas masyarakat setempat.

Wonogiri, khususnya pada Kecamatan Pracimantoro, diakui UNESCO sebagai salah satu global geopark dengan potensi geologi yang sangat besar. Salah satu desa dengan potensi cukup besar namun belum terkembangkan adalah Desa Gebangharjo, Kecamatan Pracimantoro, Kabupaten Wonogiri.

Desa Gebangharjo merupakan desa yang berada di bagian barat Kecamatan Pracimantoro. Desa ini memiliki beberapa potensi wisata antara lain :
a. Museum Karst
b. Gua Mrico
c. Gua Sodong
d. Gua Sonya Ruri
e. Gua Potro Bunder
f. Gua Luweng Sapen
g. Gua Song Gilap

Gua Song Gilap merupakan gua yang masih sangat asri dan memiliki potensi besar untuk dikembangkan menjadi objek wisata. Namun gua ini masih belum memiliki kawasan sekitar yang terbangun.

Pengembangan situs gua menjadi Kawasan wisata dapat berdampak baik pada kondisi masyarakat sekitar, khususnya masyarakat Pracimantoro. Pengaruh ini dapat dirasakan dalam beberapa aspek, antara lain:
a. Aspek Sosial
b. Aspek Ekonomi
c. Aspek Budaya

Pengoptimalan potensi wisata memerlukan adanya identifikasi mendalam mengenai potensi tersebut. Identifikasi perlu dilakukan untuk mengetahui kekuatan utama, kekurangan yang perlu diperbaiki, peluang yang ada, dan ancaman utama dari situs potensial yang terkait, yaitu Gua Song Gilap yang berlokasi di Kecamatan Pracimantoro.

Potensi wisata yang ada harus dapat dikembangkan bersama masyarakat sekitar agar hasil yang didapat juga dapat dirasakan secara langsung oleh masyarakat sekitar.

Pengembangan potensi alam yang mengarah kepada kegiatan pariwisata harus memperhatikan 4 aspek utama pariwisata, antara lain (Copper, dkk, 2000 dikutip dari Ida, dkk, 2018) :
a. Atraksi
b. Aksesibilitas
c. Amenitas
d. Ancillary

Pengembangan situs Gua Song Gilap menjadi kawasan wisata harus sesuai dengan karakter wisata gua. Gua Song merupakan sebuah wisata cagar alam. Wisata cagar alam adalah Kegiatan wisata yang daya tariknya adalah bentang alam yang dilindungi, seperti hutan lindung, taman lindung, pegunungan, dan sebagainya. Kegiatan wisata ini harus tetap menjaga kelestarian daya tarik wisata yang ada.

Konsep pengembangan kawasan wisata yang dapat digunakan pada objek penelitian sangat beragam. Penggunaannya harus disesuaikan dengan kondisi kawasan dan tujuan pengembangan yang ingin dicapai. Konsep pegembangan kawasan wisata tersebut antara lain:

\section{a. Eko Wisata}

Eko wisata menurut Peraturan Menteri Dalam Negeri No.33 Tahun 2009 adalah kegiatan wisata alam di daerah yang bertanggungjaw ab dengan memperhatikan unsur pendidikan, pemahaman, dan dukungan terhadap usahausaha konservasi sumber daya alam, serta peningkatan pendapatan masyarakat lokal. Konsep ini dapat diterapkan karena memperhatikan kelestarian alam

\section{b. Edu Wisata}

Edu wisata adalah konsep pariwisata yang memiliki unsur Pendidikan di dalamnya. Konsep ini dapat diterapkan untuk mengedukasi wisatawan terkait keanekaragaman batuan di dalam gua.

\section{c. Wisata Budaya}

Wisata budaya menonjolkan unsur kebudayaan setempat sekaligus sebagai saran promosi. Konsep ini dapat diterapkan karena wilayah sekitar Gua Song Gilap memiliki budaya y ang menarik untuk dipromosikan. 
Permasalahan utama pada objek penelitian, yaitu Gua Song Gilap, adalah ketiadaan pengelolaan kawasan sehingga berpengaruh pada berbagai macam aspek antara lain aksesibilitas, keamanan dan kenyamanan dalam kawasan, serta kekayaan alam yang harus dilestarikan ketika pengembangan kawasan dilaksanakan.

Rumusan masalah yang didapat adalah menghasilkan sebuah konsep pengembangan kawasan wisata yang memperhatikan kelestarian alam dan mampu mengoptimalkan semua potensi yang ada dalam kawasan, baik potensi ekonomi, sosial, maupun budaya.

\section{METODE}

Metode pengumpulan data yang digunakan pada penelitian kali ini adalah metode kualitatif dan kuantitatif. Metode pengumpulan data kualitatif dilakukan dengan melakukan wawancara terhadap pihak pemerintah daerah setempat serta studi literasi. Metode pengumpulan data secara kuantitatif dilakukan dengan melakukan tinjauan lapangan terhadap objek penelitian dan menghimpun data statistic dari pemerintah setempat. Data tersebut antara lain:

a. Lokasi geografis Gua Song Gilap

b. Peta persebaran gua di Pracimantoro

c. Data kependudukan

d. Data tingkat pendapatan masyarakat setempat

e. Data jumlah wisatawan di Kabupaten Wonogiri sejak tahun 2014

Data yang telah terkumpul kemudian dianalisis untuk memetakan potensi dan permasalahan yang ada di Kawasan Gua Song Gilap yang berkaitan dengan kondisi ekonomi, sosial, dan budaya masyarakat setempat.

Pemetaan potensi yang dilakukan memperhatikan empat aspek utama yaitu strength, weakness, opportunity, dan threat yang terkait dengan empat komponen wisata pada situs Gua Song Gilap serta lingkungan sekitar yaitu atraksi, aksesibilitas, amenitas, dan ancillary.

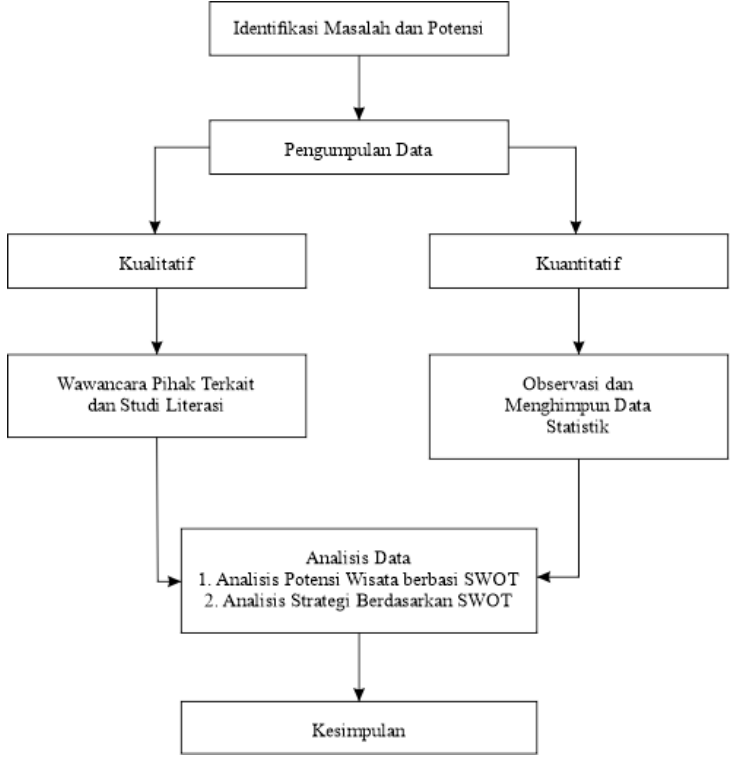

Gambar 1. Metode Penelitian

Sumber: Raden AlHuda Belva, 2020

\section{HASIL DAN PEMBAHASAN}

Kecamatan Pracimantoro terletak di Kabupaten Wonogiri, Provinsi Jawa Tengah. Kecamatan ini terdiri dari 18 kelurahan/desa. Kecamatan Pracimantoro memiliki luar wilayah seluas $142,15 \mathrm{~km} 2$.

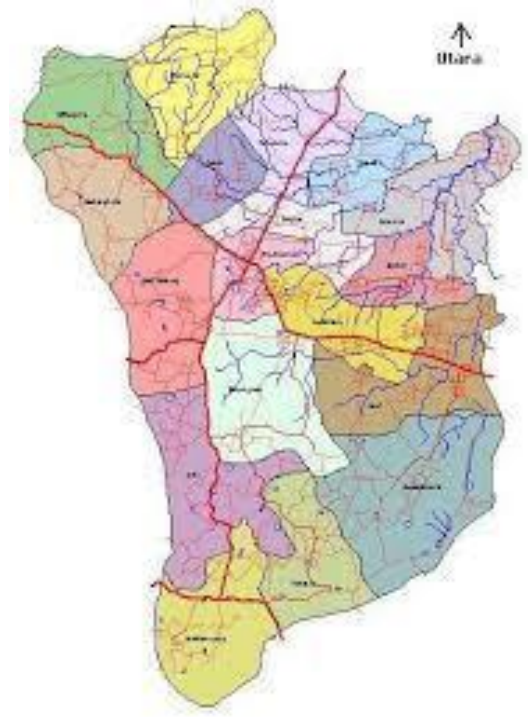

Gambar 2. Peta Kecamatan Pracimantoro Sumber:ppid.wonogirikab.go.id

Gua Song Gilap berada di salah satu desa di Kecamatan Pracimantoro, yaitu Desa gebangharjo. Desa ini memiliki luas wilayah sebesar 7,2 km2 atau 5,07\% dari luas seluruh wilayah Kecamatan Pracimantoro. 


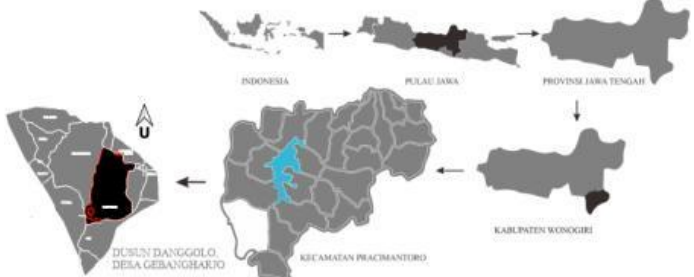

Gambar 3. Lokasi Gua Song Gilap Sumber: Peta Satelite dari Google Maps

Gua Song Gilap tepatnya berada di Dusun Danggelo, Desa Gebangharjo, Kecamatan Pracimantoro, Kabupaten Wonogiri, Jawa Tengah 57664. Lokasi situs gua berdekatan dengan embung gebangharjo yang juga menjadi potensi pengairan wilayah. Lokasi gua tidak berdekatan dengan kawasan pemukiman dan dikelilingi banyak tegalan.

Situs Gua Song Gilap memiliki daya tarik/kekuatan utama, kelemahan, peluang, dan ancaman yang perlu diidentifikasi dalam empat komponen wisata yaitu atraksi, aksesibilitas, amenitas, dan ancillary sebagai dasar pengembangan potensi yang ada.

\section{a. Atraksi}

\section{1) Kekuatan}

Gua Song Gilap merupakan situs gua yang masih sangat alami dengan kondisi stalagtit dan stalagmite yang masih sangat terjaga. Gua ini juga merupakan gua yang dapat dimasuki oleh manusia sehingga berpotensi menjadi suatu atraksi wisata.

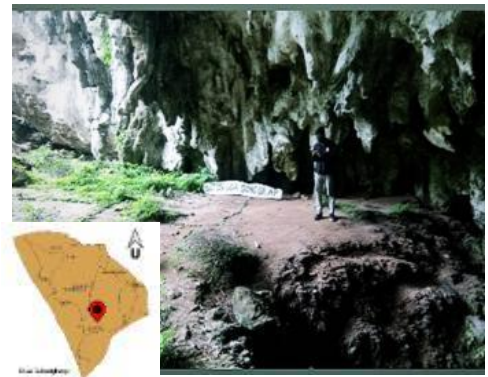

Gambar 4. Mulut Gua Song Gilap

Sumber: Raden AlHuda Belva, 2020

Situs Gua Song Gilap memiliki sungai yang mengalir di dalamnya. Sungai ini dapat dimanfaatkan untuk menambah atraksi wisata dalam gua untuk wisata petualangan karena tidak digunakan untuk pengairan rumah tangga.

Area di depan mulut Gua Song Gilap merupakan area datar terbuka yang dapat dimanfaatkan untuk berbagai kegiatan. Pada masa lampau, berdasarkan wawancara dengan masyarakat setempat, area ini digunakan untuk pertunjukkan wayang. Hal ini dapat kawasan dikembangkan untuk diaplikasikan pada kawasan Gua Song Gilap.

2) Kelemahan

Akses yang baik bagi pejalan kaki untuk menuju mulut Gua Song Gilap belum tersedia. Situs gua ini berada di lembah dengan kedalam sekitar 50 meter dari akses jalan utama. Hal ini tentunya menyebabkan akses jalan berupa tangga yang sesuai dengan standart keamanan dan kenyamanan sangat diperlukan.

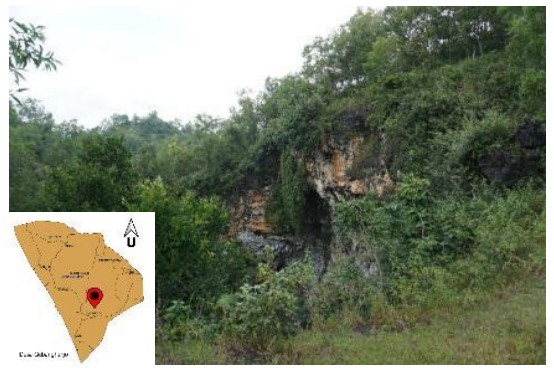

Gambar 5. Lokasi Gua Song Gilap pada lembah Sumber: Adira Damai, 2020

Kondisi gua yang ada dapat menyebabkan segmentasi bagi wisatawan yang akan datang karena kondisi Gua Song Gilap kurang ramah terhadap lansia dan rekan-rekan difabel.

Penyediaan akses pejalan kaki berupa tangga menuju mulut gua juga harus memperhatikan aspek keamanan dan kenyaman secara mendalam dengan berbagai ketentuan. Ketentuan tersebut berkaitan dengan kemiringan tangga, tinggi antar anak tangga, lebar anak tangga, tinggi railing, pemilihan material, ketersediaan bordes sebagai tempat istirahat, dan kekokohan struktur.

3) Peluang

Wilayah sekitar kawasan Gua Song Gilap masih memiliki banyak area perkebunan dengan hasil bumi yang potensial dan berkaitan langsung dengan masyarakat sekitar. Jumlah wisatawan ke Kabupaten Wonogiri dalam kurun waktu 5 tahun dari tahun 2014 hingga 2018 cenderung meningkat dari jumlah 358.330 orang pada tahun 2014 hingga mencapai jumlah 430.967 orang pada tahun 2018. Namun, terjadi penurunan pada tahun 2018. 
Tabel 1. Jumlah wisa tawan ke Kabupaten Wonogiritahun 2014-2018

\begin{tabular}{|c|c|c|c|}
\hline \multirow{2}{*}{ Tahun } & \multicolumn{2}{|c|}{ Wisatawan } & \multirow{2}{*}{ Jumlah } \\
\cline { 2 - 3 } & Mancanegara & Domestik & \\
\hline 2014 & 0 & 358.330 & 358.330 \\
\hline 2015 & 0 & 358.239 & 358.239 \\
\hline 2016 & 0 & 418.887 & 418.887 \\
\hline 2017 & 0 & 483.146 & 483.146 \\
\hline 2018 & 0 & 430.967 & 430.967 \\
\hline
\end{tabular}

Sumber: Badan Pusat Statistik Kabupaten Wonogiri, 2019

Kawasan situs Gua Song Gilap berada di Kecamatan Pracimantoro yang termasuk dalam wilayah Gunung Sewu yang diakui oleh UNESCO sebagai salah satu Global Geopark. UNESCO juga menekankan bahwa kawasan tersebut harus dilindungi dan dimanfaatkan untuk wadah pengembangan Geotourism. Hal tersebut direspon oleh pemerintah daerah setempat dengan membuat program-program yang berkaitan dengan pengembangan kawasan wisata.

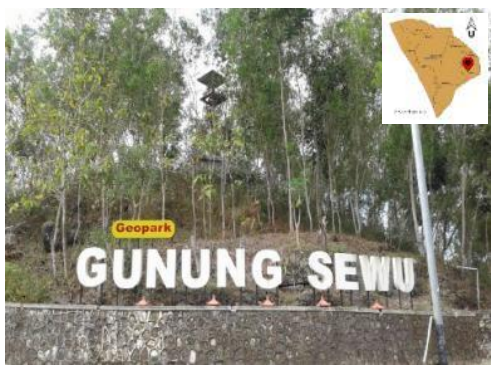

Gambar 6. Pra cimantoro masuk dalam Kawasan Geopark Gunung Sewu

Sumber: gln.kemdikbud.go.id

Kabupaten Wonogiri memiliki tingkat investasi yang cukup tinggi. Menurut data Dinas Penanaman Modal Satu Pintu Wonogiri, nilai investasi di Wonogiri pada tahun 2019 mencapai angka Rp. 11.900.000.000 (Dinas Penanaman Modal Satu Pintu Kabupaten Wonogiri, 2019, dikutip dari Perdana, 2020). Tingginya angka investasi dapat disalurkan pada pengembangan potensi wilayah yang ada untuk kepentingan masyarakat umum.

Masyarakat desa di sekitar situs Gua Song Gilap dalam lingkup Kecamatan Pracimantoro memiliki potensi kerajinan yang cukup menjanjikan. Potensi masyarakat sekitar dapat menjadi daya Tarik bagi wisatawan untuk datang ke Pracimantoro sehingga memudahkan pengembangan potensi wisata yang ada, termasuk di dalamnya adalah situs Gua Song Gilap.

Desa Lebak memiliki potensi kerajinan berbahan kayu. Kerajinan ini berupa miniatur motor Harley Davidson. Kerajinan ini menggunakan bahan dasar berupa kayu baru maupun bekas. Penggunaan kayu bekas tersebut juga dapat mengurangi limbah kayu pada lingkungan sekitar sehingga meminimalisir pencemaran lingkungan.

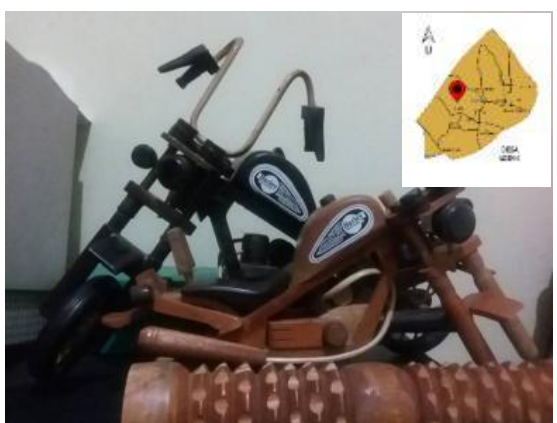

Gambar 7. Kerajinan miniatur motor berbahan kayu

Sumber: bektitrias143.wordpress.com

Desa Sumber Agung memiliki potensi kerajinan pirografi. Pirografi, adalah seni lukis pada kayu atau bahan lainnya dengan cara membakar tanda atau coretan-coretan lukisan yang dihasilkan dari alat yang dipanaskan secara terkendali (Hasrullah, 2019).

Kerajinan ini berkembang dari ide pemuda desa setempat yang cukup tertarik dengan pengolahan kayu. Bahan yang digunakan dalam membuat kerajinan ini dapat berupa kayu ataupun triplek. Pemilihan triplek merupakan alternative dari penggunaan bahan kayu yang harganya cukup mahal.

Cara pembuatan kerajinan pirografi diawali dengan menghaluskan kayu atau triplek yang akan menjadi alas gambar. Kayu atau triplek yang telah dihaluskan kemudian digambar dengan pola sesuai dengan permintaan. Pola yang sudah tergambar kemudian dipanaskan untuk menghasilkan karya seni pirografi. Seni ini merupakan seni yang membutuhkan ketelitian dan kesabaran dalam pengerjaannya sehingga dapat memiliki nilai jual yang tinggi sesuai dengan kompleksitas gambar yang diminta. 


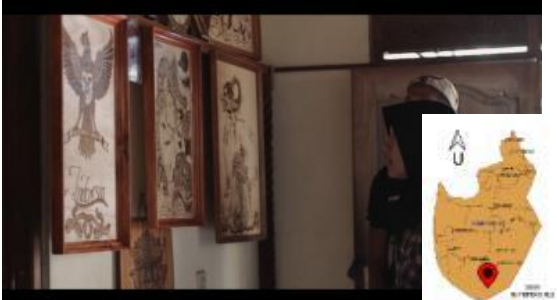

Gambar 8. Kerajinan pirografi Desa sumuer Agung

Sumber: Kecamatan Pracimantoro

Desa Gebangharjo memiliki potensi kerajinan blangkon yang digagas oleh pemuda setempat. Kerajinan ini mulai berkembang di Desa Gebangharjo pada tahun 2013, namun jumlah pengrajin yang ada terus menurun. Pemerintah Desa Gebangharjo memberikan perhatian kepada industri kerajinan blangkon yang ada agar terus berkembang baik dalam sekala lokal, nasional, bahkan internasional.

Kegiatan produksi kerajinan blangkon di Desa Gebangharjo masih dilakukan dengan cara tradisional dan dalam skala industri rumahan, namun memiliki potensi untuk terus berkembang. Hasil produksi kerajinan blangkon saat ini sudah dikirim hingga ke Kota Surakarta.

Kegiatan produksi kerajinan blangkon ini merupakan implementasi dari semangat kebudayaan masyarakat setempat untuk bangga dalam menggunakan pakaian tradisional. Hal ini dapat melestarikan kebudayaan setempat dan berpotensi berkembang menjadi wisata budaya. Pola pikir dengan tujuan yang besar sangat diperlukan dalam sebuah pengembangan potensi masyarakat.

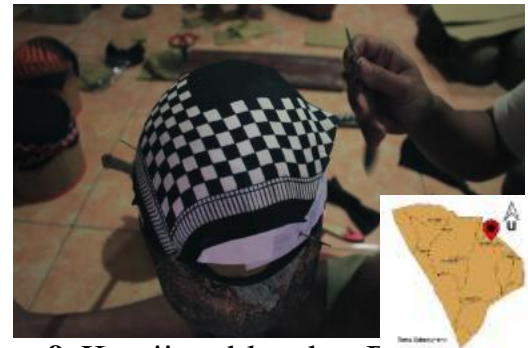

Gambar 9. Kerajinan blangkon Lesa ucuaugharjo Sumber: Kecamatan Pracimantoro

Desa Suci memiliki potensi industri batik yang dinamakan Batik Cikal. Industri batik ini mulai berkembang pada tahun 2018 dan digagas oleh pemuda setempat. Kegiatan produksi batik dilakukan dengan memaksimalkan potensi ibu rumah tangga, khususnya di Dusun Ploso. Batik Cikal diharapkan dapat menjadi ikon wilayah setempat.

Kegiatan prosuksi Batik Cikal saat ini bekerja sama dengan produsen batik dari Pacitan dalam berbagai hal, seperti penyediaan alat membatik dan sarana penjualan. Kegiatan produksi yang dilakukan di Dusun Ploso, Desa Suci saat ini difokuskan pada pembuatan desain dan belum mencakup pewarnaan.

Pemerintah desa setempat memberikan dukungan terhadap pengembangan industri batik dengan memasukkan Batik Cikal dalam rencana pembangunan jangka menengah, sehingga terdapat anggaran untuk kelengkapan alat produksi.

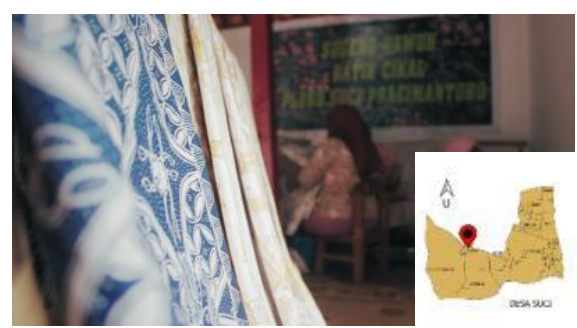

Gambar 10. Kerajinan batik cikal Desa Suci Sumber: Kecamatan Pracimantoro

4) Ancaman

Ancaman untuk pengembangan situs Gua Song Gilap menjadi Kawasan wisata adalah kondisi tanah sekitar yang berada di dataran tinggi dan berkontur. Kondisi ini memungkinkan terjadinya longsor yang dapat mengancam keselamatan masyarakat maupun pengunjung atau wisatawan. Tanah berkontur akan rawan longsor ketika mengandung kadar air yang tinggi sehingga diperlukan perhatian dan antisipasi khusus dalam pengembangan Kawasan wisata di situs Gua Song Gilap.

\section{b. Aksesibilitas}

1) Kekuatan

Akses menuju situs Gua Song Gilap saat ini dapat dilalui dengan kendaraan roda dua maupun roda empat.

Lokasi Gua Song Gilap dari jalan utama masih dangat terjangkau secara jarak maupun waktu. Lokasi Gua Song Gilap dapat diakses melalui jalan masuk yang sama dengan museum karst. Penunjuk jalan menuju situs Gua Song Gilap cukup jelas sehingga meminimalisir kemungkinan pengunjung menuju ke arah yang salah. 
2) Kelemahan

Kondisi jalan utama yang dapat dilalui kendaraan masih merupakan jalan berbatu. Jalan ini masih cukup sulit untuk dapat dilalui secara dua arah karena belum mengalami perkerasan.

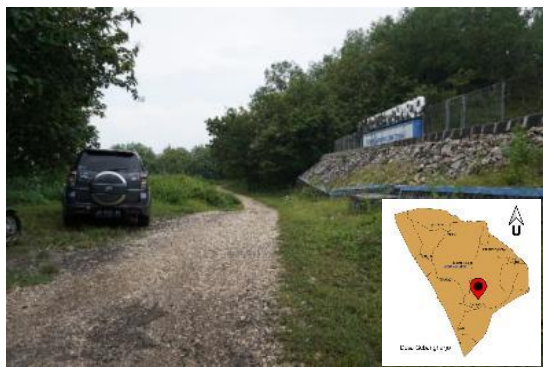

Gambar 11. Akses jalan menuju Gua Song Gilap Sumber: Adira Damai, 2020

Perbaikan jalan utama diperlukan untuk memudahkan akses kendaraan bermotor menuju situs Gua Song Gilap, karena berkaitan erat dengan jumlah pengunjung yang mau datang ke situs Gua Song Gilap. Kualitas jalan menurut standar meliputi lebar jalan yang cukup, perkerasan jalan yang memadai, drainase, dan ketersediaan bahu jalan

3) Peluang

Pemerintah setempat memberikan perhatian yang baik kepada sector pariwisata dengan juga bekerja sama dengan berbagai pihak. Perhatian pemerintah dapat memberikan peluang perbaikan dan pengoptimalan potensi wisata yang ada, termasuk pada aspek aksesibilitas.

\section{4) Ancaman}

Tidak terdapat ancaman pada aspek aksesibilitas kawasan karena permasalahan yang ada berasal dari dalam area kawasan Gua Song Gilap.

\section{c. Amenitas}

1) Kekuatan

Kekuatan kawasan pada aspek amenitas yang terkait dengan sarana dan prasarana awasan hanya terdapat pada ketersediaan pengairan pada kawasan Gua Song Gilap.

Embung Gebangharjo yang berada di sebelah utara situs Gua Song Gilap memiliki potensi pengairan wilayah sekitar. Pengairan dapat dilakukan untuk kegiatan rumah tangga maupun kegiatan perkebunan.

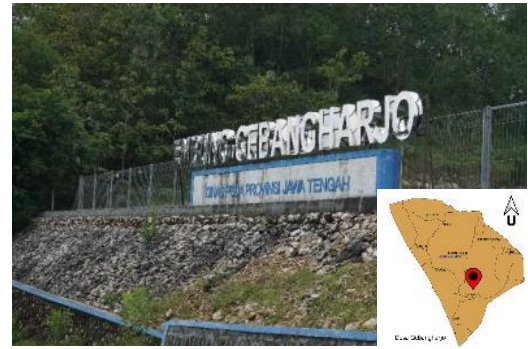

Gambar 12. Embung Gebangharjo Sumber: Adira Damai, 2020

2) Kelemahan

Kelemahan kawasan Gua Song Gilap pada aspek amenitas adalah ketiadaan sarana dan prasarana pendukung untuk pengembangan sebuah kawasan wisata.

Sarana dan prasarana tersebut berkaitan dengan kegiatan yang akan diwadahi dalam kawasan dan juga elemen penunjang kegiatan tersebut, seperti penyediaan listrik dan pengolahan limbah kawasan.

\section{3) Peluang}

Program pemerintah setempat untuk pengembangan kawasan wisata berpotensi pembangunan sarana dan prasarana agar objek penelitian ini, yaitu Gua Song Gilap dapat layak menjadi sebuah kawasan wisata.

\section{4) Ancaman}

Pendanaan yang belum mencukupi untuk melaksanakan pembangunan sarana dan prasarana menjadi ancaman terhadap usaha pengembangan kawasan wisata pada aspek amenitas.

\section{d. Ancillary}

1) Kekuatan

Masyarakat sekitar dapat diedukasi untuk menjadi pengelola kawasan wisata yang akan dikembangkan dengan pembentukan Kelompok Sadar Wisata (Pokdarwis) agar masayarakat tersebut dapat merasakan manfaat dari pengembangan kawasan Gua Song Gilap sebagai kawasan wisata.

\section{2) Kelemahan}

Kelompok masyarakat yang berperan sebagai pengelola situs Gua Song Gilap saat ini belum terbentuk. Hal ini menyebabkan situs gua belum terkelola dengan baik dan belum terkembangkan sebagai kawasan wisata. 
3) Peluang

Program pemerintah setempat sangat mendukung untuk pengembangan potensi daerah sebagai kawasan wisata. Hal ini diwujudkan dengan adanya pendamping desa dari pemerintah kecamatan yang bertugas mendampingi masyarakat dalam pengembangan potensi daerah.

4) Ancaman

Tidak ditemukan ancaman pada aspek ancillary di kawasan Gua Song Gilap.

Berdasarkan analisis SWOT yang telah dilakukan pada tiap komponen wisata, dikemukaan berbagai potensi Gua Song Gilap, kekurangan yang masih perlu diperbaiki, peluang dari wilayah sekitar yang perlu dikembangkan agar dapat mendukung pengembangan kawasan wisata, serta beberapa ancaman yang perlu diantisipasi. Potensi dan permasalahan yang ada melahirkan strategi dalam pengembangan kawasan wisata di situs Gua Song Gilap berdasarkan empat komponen wisata, antara lain:

\section{a. Atraksi}

Pengembangan kawasan wisata mengggunakan konsep eco-tourism yang berorientasi pada nilai-nilai pelestarian lingkungan, nilai budaya masyarakat, pengembangan masyarakat sekitar, pengembangan usaha kecil dan koperasi, serta pembangunan berkelanjutan (Choy, 1998 yang dikutip dari Prayudi dkk, 2017).

Pembangunan berkelanjutan memiliki empat prinsip utama, yaitu konservasi, edukasi, partisipasi, dan ekonomi.

Eko wisata menurut Peraturan Menteri Dalam Negeri No.33 Tahun 2009 adalah kegiatan wisata alam di daerah yang bertanggungjawab dengan memperhatikan unsur pendidikan, pemahaman, dan dukungan terhadap usahausaha konservasi sumber daya alam, serta peningkatan pendapatan masyarakat lokal.

Eko wisata memiliki beberapa prinsip menurut Choy, 1998 yang dikutip dari Prayudi dkk, 2017. Prinsip-prinsip tersebut antara lain adalah :

1) Kawasan wisata dengan penerapan eko wisata harus terpusat pada bentang alam dan budaya masyarakat setempat yang masih asli.

2) Masyarakat sekitar lokasi wisata harus menerima manfaat sebesar-besarnya dari kegiatan pariwisata yang ditawarkan.

3) Kegiatan wisata yang menerapkan eko wisata harus dapat memberikan pengalaman dan pengetahuan bagi wisatawan untuk sadar akan kondisi lingkungan alam dan budaya setempat.

4) Kegiatan wisata yang ada harus tetap memperhatikan kondisi kelestarian lingkungan alam, sehingga tidak merusak alam sekitar. Hal ini harus diterapkan dalam rencana jangka pendek dan Panjang.

5) Pengelolaan Kawasan wisata harus memperhatikan kaida-kaidah pelestarian lungkungan sekitar.

Strategi yang dapat dilakukan dalam pengembangan kawasan wisata berbasis eko wisata anatara lain :

1) Mengutamakan situs Gua Song Gilap sebagai atraksi wisata dengan tetap menjaga kelestarian alam sekitarnya.

2) Memaksimalkan vegetasi yang ada sebagai elemen kawasan.

3) Melakukan pengolahan limbah dalam kawasan agar tidak mencemari lingkungan sekitar.

4) Mengoptimalkan penggunaan energi alami.

5) Menyediakan wadah bagi kegiatan pengembangan masyarakat sekitar di bidang ekonomi, sosial, dan budaya.

Potensi dari wilayah sekitar dalam lingkup Kecamatan Pracimantoro juga dapat membantu menarik kedatangan wisatawan lokal maupun mancanegara sehingga diperlukan pengoptimalan dari segi kualitas dan promosi.

Pendanaan untuk modal pengembangan wisata potensi diperlukan untuk meningkatkan produksi dari potensi-potensi wilayah yang berupa industri rumahan.

Promosi diperlukan agar produk-produk lokal dapat menjangkau pasar yang lebih luas. Promosi dapat dilakukan dengan memaksimalkan sosial media yang sedang sangat berkembang di masyarakat. Sosial media yang dapat digunakan antara lain instagram, facebook, dan lain-lain. Promosi 
yang diperlukan selain promosi produk adalah promosi lokasi potensi yang ada sebagai daya tarik wisata budaya, sehingga wisatawan juga dapat tertarik untuk melihat proses produksi yang terkait dengan kekayaan potensi budaya masyarakat Pracimantoro.

Ancaman pada atraksi wisata Gua Song Gilap, yaitu potensi longsor karena kondisi kontur yang ada, perlu diantisipasi untuk mencapai tingkat keamanan yang ideal bagi pengunjung maupun pengelola kawasan. Antisipasi dapat dilakukan dengan penggunaan konsep struktur yang kokoh dan stabil ketika pembangunan sarana dan prasarana dilaksanakan.

\section{b. Aksesibilitas}

Akses jalan menuju situs Gua Song Gilap perlu diperbaiki karena kondisinya yang masih berbatu dan kurang ideal untuk dilalui mobil dari dua arah.

Perbaikan jalan yang terkait dengan keamanan akses menuju Gua Song Gilap perlu dilakukan dengan mempertimbangkan berbagai faktor seperti material jalan, lebar jalan, drainase, dan ketersediaan bahu jalan.

Material jalan yang dapat digunakan antara lain beton dan aspal. Masing-masing material memiliki kelebihan dan kekurangan, namun jalan berbahan beton lebih sering digunakan saat ini karena lebih tahan lama dan kuat menahan beban berat kendaraan yang melintas.

Lebar jalan yang ideal untuk dilalui kendaraan dari dua arah adalah 7 sampai 8 meter.

Drainase yang baik pada jalan diperlukan agar tidak terjadi genangan air yang membahayakan pengemudi. Jalan perlu memiliki kemiringan ke arah tepi dan tersedia saluran air di tepi jalan.

Bahu jalan ataupun jalur lambat diperlukan agar kendaraan yang antri untuk masuk ke kawasan wisata tidak tercampur dengan kendaraan yang melintas, sehingga tidak menyebabkan kemacetan. Bahu jalan juga dapat digunakan untuk motor melintas agar tidak bercampur dengan kendaraan mobil ataupun bis.

Faktor keamanan sangat perlu diperhatikan karena terdapat jurang di sebelah utara jalan di area sekitar kawasan situs Gua Song Gilap, sehingga diperlukan terdapat pagar pembatas yang seusai standar keamanan kendaraan bermotor.

Potongan standar kualitas jalan dapat dilihat pada gambar berikut.

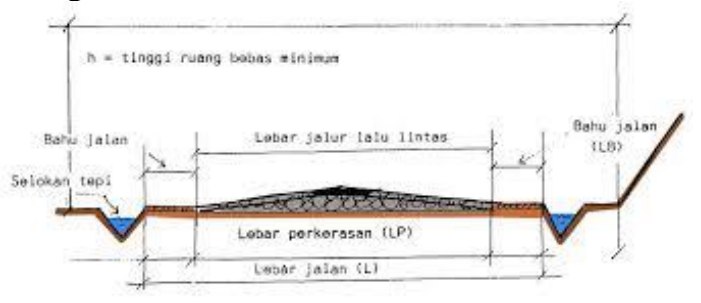

Gambar 13. Standar kualitas jalan Sumber: ciptakarya.pu.go.id

\section{c. Amenitas}

Pengoptimalan embung gebangharjo perlu dilakukan sebagai sumber air wilayah sekitar yang nantinya dapat juga digunakan sebagai sumber air dari kawasan wisata saat sudah dikembangkan. Hal ini dibutuhkan agar pengairan kawasan dapat dilakukan secara mandiri.

Pembangunan sarana dan prasarana juga diperlukan untuk menunjang kegiatan yang ditargetkan akan diwadahi pada kawan wisata terkembang. Sarana dan prasarana tersebut antara lain :
1) Restoran
2) Tempat ibadah
3) Toilet
4) Loket tiket
5) Pos keamanan
6) Lahan parkir
7) Tempat istirahat bagi wisatawan
8) Penginapan
9) Penyediaan aliran listrik kawasan
10) Penyediaan pengolahan limbah kawasan
11) Penyediaan pengairan kawasaan

Pengolahan limbah dalam kawasan nantinya diperlukan agar kelestarian alam wilayah sekitar dapat terjaga dari pencemaran. Hal ini sesuai dengan prinsip eko wisata yang digunakan dalam pengembangan kawasan.

\section{d. Ancillary}

Edukasi kepada masyarakat mengenai cara dan manfaat dari pengembangan potensi wisata sebagai kawasan wisata sagat diperlukan agar masyarakat setempat dapat menjadi pengelola kawasan dan merasakan manfaatnya. Edukasi tersebut dapat dilakukan melalui pendamping 
desa yang sudah dimiliki oleh pemerintah setempat.

Pembangunan sarana dan prasaran pada kawasan wisata terkembang juga harus memperhatikan kegiatan pengelolaan. Kantor pengelola kawasan diperlukan agar kegiatan pengelolaan dapat berjalan sehingga dapat menghasilkan kebijakan-kebijakan yang tepat untuk terus mengembangkan kawasan Gua Song Gilap.

\section{KESIMPULAN}

Pengembangan potensi situs Gua Song Gilap di Kecamatan Pracimantoro untuk menjadi kawasan wisata diharapkan mampu menjadi solusi dari berbagai permasalahan masyarakat sekitar. Pengembangan kawasan juga harus memperhatikan peluang yang ada dari wilayah di sekeliling kawasan serta mengantisipasi ancaman yang ada.

Peluang yang ada di sekitar kawasan perlu diperhatikan untuk menambah daya tarik wisata. Sedangkan ancaman yang ada perlu diantisipasi untuk mencapai tingkat keamanan yang ideal.

Berdasarkan identifikasi dan analisis yang dilakukan, konsep pengembangan kawasan wisata yang sesuai untuk situs Gua Song Gilap adalah konsep eko wisata yang mengedepankan pelestarian lingkungan, beroientasi pada pengembangan masyarakat, dan menjalankan prinsip pembangunan berkelanjutan.

\section{UCAPAN TERIMAKASIH}

Penulis mengucapkan terima kasih kepada pihak Pemerintah Kecamatan Pracimantoro dan masyarakat setempat atas dukungannya dalam proses penelitian ini. Penelitian ini juga dapat berjalan melalui pendanaan dari dana PNBP Universitas Sebelas Maret tahun anggaran 2020.

\section{REFERENSI}

Badan Pusat Statistik Wonogiri. (2019). Kecamatan Pracimantoro Dalam Angka 2019. https://wonogirikab.bps.go.id

Hamdani. 2018. Wisata ke Gua Song Gilap Pracimantoro Sambil Menyusuri Jejak Prasejarah. https://joglosemarnews.com/2018/09/wisa ta-ke-gua-song-gilap-pracimantorosambil-menyusuri-jejak-prasejarah/. diakses pada tanggal 17 Desember 2020.

Hamdani. 2019. Mau Tahu Daftar Nama Desa Dusun dan Potensi di Kecamatan Pracimantoro Wonogiri? Simak Penjelasan Lengkap Berikut Ini. https://joglosemarnews.com/2019/10/. diakses tanggal 20 Desember 2020.

Mustofa, Akhmad, dkk. 2017. Identifikasi Pengembangan Desa Wisata Di Kabupaten Wonogiri. Universitas Slamet Riyadi. Surakarta.

Peraturan Menteri Dalam Negeri No.33 Tahun 2009 tentang Pedoman Pengembangan Ekowisata Di Daerah

Perdana, ed. 2020. Pengunjung Waduk Gajah Mungkur Lesu, Beralih ke Wisata Desa \& Swasta.

https://radarsolo.jawapos.com/read/2020/ 01/17/175214/. diakses pada tanggal 1 Desember 2020.

Pertiwi, Ni Luh Made. 2020. 5 Geopark Indonesia yang Masuk UNESCO Global Geopark.

https://travel.kompas.com/read/2020/07/0 8/181100427/5-geopark-indonesia-yangmasuk-unesco-global-geopark?page $=$ all . diakses pada tanggal 18 Desember 2020.

Prayudi, dkk. 2017. Membangun Desa Ekowisata. Universitas Pembangunan Nasional "Veteran". Yogyakarta.

Reforma, Adira Damai. 2020. Identifikasi Potensi Pariwisata Pracimantoro Dari Geopark Hingga Kebudayaan Daerah. Universitas Sebelas Maret. Surakarta.

Samparaya, Citra Fany. 2018. Negara dengan Pertumbuhan Pariwisata Tercepat Sedunia, Indonesia Peringkat 9. https://travel.kompas.com/read/2018/10/0 4/181500527. diakses pada tanggal 26 November 2020.

Wanda, Ida Bagus Kade, dkk. 2018. Pengaruh Pengembangan Komponen Destinasi Wisata Terhadap Kepuasan Pengunjung (Survei Pada Pengunjung Situs Trowulan). Universitas Brawijaya. Malang 